\title{
A sea uprooted: islandness and political identity on Chiloé Island, Chile
}

\author{
Beatriz Bustos \\ Department of Geography, University of Chile, Chile \\ bibustos@uchilefau.cl
}

\begin{abstract}
Álvaro Román
Institute of Geography, Pontifical Catholic University of Chile, Chile ajroman@uc.cl (corresponding author)
\end{abstract}

\begin{abstract}
In 2016, the people of Chiloé, an island in Southern Chile, mobilised against the Chilean state for a period of over three weeks. The conflict was triggered by an environmental crisis that affected the main economic activities of the island: salmon farming and artisanal fisheries. This article argues that 'islandness' should also be understood as a political stance toward the state. Based on in-depth interviews and an exploration of the concept of islandness, the paper examines the mayo chilote, and contributes an empirical reflection on the transformation of islandness as a political position by analysing the tension between two narratives, each demanding different treatment for the island: demand for redistribution led by those directly affected by economic losses resulting from the crisis, and autonomy as development, involving deeper and broader criticism of historical relations with Chile. We aim to contribute to island studies by providing a non-binary understanding of processes of identity and social mobilisation.
\end{abstract}

Keywords: Chiloé, conflict, islandness, islands, salmon farming, social mobilisation

https://doi.org/10.24043/isj.91 • Received December 2018, accepted June 2019

(C) 2019-Institute of Island Studies, University of Prince Edward Island, Canada.

\section{Introduction}

Chiloe is an island located in Southern Chile, the economy of which-based on salmon exports-makes a crucial contribution to the national economy. However, from the island's perspective, the relationship with the mainland is more complicated. There is a strong sense of pride in being the last Spanish stronghold to fall to the Chilean state under the 1826 Tantauco Treaty, almost ten years after the rest of the country became independent. Since then, the state has made concerted efforts to secure territorial control and to gain legitimacy from Chilotes (the name given to the island's inhabitants) by promoting the exploitation of diverse natural resources. Between the 1930s and 1960s, the industrialisation of fishing and timber activities was encouraged on the island, although this prompted record levels of outmigration due to the resulting lack of jobs and economic opportunities for inhabitants. The 
1970s saw the economic neoliberalisation of the island, and the salmon farms installed around the coast and Inner Sea began to blossom in the 1980s and were booming globally by the following decade. The salmon industry was the driving force behind a complete transformation of existing modes of production on the island, converting it from a livelihoodbased system to a proletarianised society (Barrett, Caniggia, \& Read, 2002; Barton \& Román, 2016; Hidalgo et al., 2015).

As is the case with other islands around the world, Chiloé's identity is not a homogenous construction. It is riddled with histories and expectations contributed by each inhabitant and social group. As such, the question becomes how those trajectories and identities translate into a political position toward the state and toward particular development trajectories pursued in a given space. This process involves a combination of place-identity, context, actors, events and local rhythms, along with a broad spectrum of political positions, all of which come together in confrontation during a moment of crisis, in which the various elements look to their past as they consider their future (Baldacchino, 2005; Conkling, 2007). The present paper examines the process of political positioning on the island of Chiloe in a context of environmental and social crisis, namely the so-called mayo chilote of 2016, during which islanders confronted policy solutions implemented by the state to address the effects of a series of algal bloom events on salmon and artisanal fisheries.

We argue that the concept of 'islandness' has become central to the political discourse and strategy that opposes ongoing state intervention, and we identify long-term changes in attitudes toward development. In particular, we explore the role of resentment as an emotional ground on which to articulate political positions based on prior experiences of exclusion (Cramer, 2016). The present paper contributes by providing empirical evidence of the emergence of two opposing political positions founded on islandness.

To discuss the evolving interaction between Chiloé and the state in terms of development projects, we begin with a couple of assumptions about the historical process that has occurred. The first assumption is that the modernisation project was successful inasmuch as Chiloé today is well integrated into a globalised economy and the logics of modernity. However, this came at the cost of excluding people and livelihoods from the benefits of the modern promise. We therefore identify two positions on the part of Chilotes: one group demands a redistribution of the costs and benefits of the modern project, and the other group, in light of the uniqueness of Chiloé's culture and identity, calls for a redefinition of the concept of development.

The second assumption is that the learning outcome from salmon industry expansion in Chiloé over the last 40 years is dominated by distrust of the state. Considering that the state has actively promoted the expansion of the industry through legal and administrative means and that, during previous crises (allegations of waste dumping in 1997 and Immuno Salmon Anemia [ISA] virus - a disease affecting Atlantic Salmon-in 2008), the survival of the industry was prioritised above any social or environmental considerations, Chilotes have developed a profound distrust of state institutions as decision-making spaces, which in turn has eroded their sense of belonging to the Chilean state and led them to feel like second-class citizens.

Section two explores the concept of islandness and the need to consider this reality as a political position. Section three describes the salmon project in Chiloé. Section four describes the social mobilisation that occurred in 2016, and presents the main drivers and actors behind 
it. Section five offers evidence from the mayo chilote to illuminate the emergence of political islandness narratives. Finally, section six discusses implications for the case of Chiloé and for island studies in general.

\section{Islandness as a political position}

Island and island identity are interwoven concepts that combine physical, relational and emotional issues. Hay (2013, p.217) refers to a "bounded sensibility" that shapes the sense of uniqueness and distinction, even from other islands within an archipelago. No matter how connected an island is, the physical barrier of the sea configures a specific experience of territory. This means that terms often used to describe island-isolated, remote, peripheral yet sheltering local values - are not always accurate when defining relationships with other land areas, structures, or portions of sea. Hay (2013) highlights the unclear nature of island borders and compares them to ecotones, a concept which refers to identities open to change, adaptation and incorporation of new components. As such, island identities are dynamic because of the continuous and ongoing interpretation of their cultural content, physical conditions and social processes, all of which affect processes of rationalisation and emotionality.

Furthermore, literature on islandness stresses the complexity of the sea (Hayward, 2012; Pugh, 2016; Rankin, 2016). It is not just the element that separates the island from the continent; it also contains and constrains a set of relations that define a unique viewpoint from which to identify and understand a particular legacy. Following on from Heidegger (2009), we propose that the sea constructs spaces that go beyond the island itself, involving a process by which islanders establish relationships with new components. In a sense, islands move (Pugh, 2013) as a result of the unstoppable process of resignification of old and the creation of new components. Thus, interactions between fishing grounds, salmon farming enclosures, marine waste dumps and algal blooms drive changes to the ways in which islanders form their points of view. Moreover, islands are political artefacts in themselves rather than mere peripheral territories of continents or larger states.

The relationships between islands and continental powers have often been a source of controversy. Differentiating themselves from the rest of the world potentially allows islanders to affirm their particularities in such a way that they can control the rhythm and the intensity of changes resulting from their growing insertion into- particularly economic and politicalglobal trends (Ducros, 2018; Randall et al., 2014). The strength of global economic flows overwhelms local capacity to make decisions about the future, resulting in processes that prioritise the efficient movement of capital from one place to another rather than promoting local progress and development (Fløysand, Barton, \& Román, 2010). Furthermore, islands are often seen as being behind the curve in terms of self-government, self-control and rationale, and the perspectives and constructions of residents tend to be neglected, obscuring their political positions and presenting them as heavily dependent on central power (Lois, 2013). Thus, the political positions of islanders are defined in terms of the continental powers to which they are forced to adapt in order to maintain the possibility of participating in discussions about their territories.

Consequently, criticism of mistreatment by state authorities is common in island communities. It constitutes not only an asymmetrical relationship between smaller and larger pieces of land, but one characterised by marginalisation. Islanders are generally forced to 
accept decisions made by central powers regarding their peripheral position, and these decisions tend to be influenced by traditional views of islands as differing from the expectations of continental societies. The latter determine requirements and regulations that will in theory value the specificities of islands and deal with those environmental issues that are more visible in sea-locked territories (Pugh, 2018). We propose that the sea is not the only component that influences island identity, but it does help to explain the emotional factor involved in the construction of the unique viewpoints of islanders. The sense of unfairness regarding state decisions involving "historical disappointments" (Mascareño et al., 2018, p.7) is justifiable given backgrounds of abandonment, exploitation of natural resources, and exclusion (Mountz, 2015). Confrontation with continental powers and the notion of distinctiveness shape islandness, which constitutes a set of political positions that emerge in these contexts. Simply put, islanders are burdened simultaneously with emotional and rational issues when posing a political position.

Given the variety of elements that make up this burden-personal and familial backgrounds, specific interests in a given event, and propinquity - it is possible that islanders find themselves unable to form a direct consensus (Vannini, 2011), regardless of their number. Islandness involves the formation of an emotionally and rationally defined, yet unpredictable position. As such, we consider that there is a gap in the literature with regard to how this emotional range transforms into a political position toward the state. We aim to contribute to island studies by providing a non-binary understanding of processes of identity and social mobilisation. In this context, islandness is not a viewpoint that continuously fluctuates between emotional and rational, but rather a complex construction that incorporates the feeling of inhabiting an island along with experiences of exclusion, marginalisation, diminished capacity, and the struggle to influence state decisions. Islandness refers to political positions shaped by collective identities involving the sea and confrontation with state decisions.

Melucci (1995) provides an important framework within which to consider how collective identity comes to be and how it connects with collective action. While the former is the result of "purposes, resources and limits within a system of opportunities and constraints" (Melucci, 1995, p.43), the latter is a process of "constructing an action system [...] incorporated in a given set of rituals, practices, cultural artefacts; they are framed in different ways but they always allow some kind of calculation between ends and means, investments and rewards" (Melucci, 1995, p.44). Although Melucci acknowledges the emotional component, he does not propose a way in which affection and emotional attachment to place configure a kind of political subject.

Of particular relevance to our work is the emotion of disappointment caused by unfulfilled expectations. Once disappointment in the state has been expressed, it can be addressed or redefined by continental powers, thus mitigating the confrontation. Disappointment can become structural, with actors behaving politically and waiting for the next let-down. In this sense, islandness acts as a 'performative' device (Vannini, 2011), and positions taken in opposition to continental powers are made more extreme in order to ensure that at least some of the islanders' objectives are achieved within this controversial relationship. Cramer (2016) uses the term 'politics of resentment' in reference to political positions that stress the gap in values and principles between local and external actors, with the latter ignoring living conditions and, therefore, making unfair decisions in terms of distribution. 
For Cramer (2016, p.9), the politics of resentment also involves a framing of 'us' versus 'them', and arises from interaction between economic insecurity, social identities, and resentment. As such, we propose the addition to Melucci's framework of the idea that collective identity emerges during moments of crisis, driven by a perceived need to find a 'common enemy', a 'them' that represents the frustration with the state of politics, but also the sense of grievance toward the common element in island identity: the sea. Together, identity, mobilisation, and resentment provide a framework for islandness as a political position that carries the memory of frustrating past events, resistance against the arrogance of central powers in their understanding (or lack thereof) of local complexities, and a commitment to remain part of a special community that projects uniqueness in a globalised world.

\section{The salmon promise in action: trajectories toward resentment}

Over the past 40 years, Los Lagos has become a commodity region, in other words, a region with an economic and ecological metabolism revolving around mono-production of Atlantic salmon for export markets (Daher, 2003; Bustos \& Prieto, 2019). The salmon industry, originally comprised of over 200 small and medium-sized firms, has evolved into a global production network dominated by 5-8 major players, which have made Chile the secondbiggest salmon producer globally (Barton \& Román, 2016). In this section, we will explore the role and effect of state intervention in turning Los Lagos into a salmon-producing region. More specifically, we want to connect the emergence of economic actors as neoliberal citizens (Ong, 2006) with the fundamental elements of the relationship that shaped the politics of resentment that lay at the core of the May 2016 conflict.

The Chilean state played an active role in the introduction and industrialisation of salmon as a commodity in the Los Lagos region. The first step was the enactment in 1991 of the Fisheries and Aquaculture Law (No. 18,892), and in the 2000s a second stage began with the implementation by the state of a cluster policy that promoted a logic of the value chain between suppliers and firms in the region. The institutional framework operated under the political logic of free competition: any firm requesting permission to operate or designate Areas Apt for Aquaculture (AAA) was granted approval. For individuals, this meant promoting entrepreneurial and innovation skills connected with the dominant salmon industry. The state offered subsidies and loans to those willing to incorporate themselves into the industry, and increased oversight of other livelihood activities, making continuation of agriculture or timber logging commercially inviable.

It was the implementation of this second stage of the salmon process that had the greatest impact on the Chilote reality. Traditions and identity were seen as obstacles to development, while raising money and integration into the global economy were understood as being primary goals to ensure the availability of previously inaccessible goods and services. Barton and Fløysand (2010) suggest that this change went unnoticed at first, as the opportunities generated by the industry represented a huge difference in terms of material conditions. While institutional efforts succeeded in imposing the discourse of Los Lagos as a salmon region, little attention was paid to the political impact on other activities in the region. The abandonment of agricultural land due to the exodus of workers and the reduction in artisanal fishing activity due to loss of biomass led to an alternative discourse surrounding the role of the industry in the region: while benefits were significant, they were only for the few. 
As can be seen in Figure 1, salmon operations began to dominate the Inner Sea, affecting navigation routes and urbanisation of coastal areas. The presence of salmon infrastructure on the shoreline-in the form of control and accommodation facilities, and small harbours for the boats which ferry workers to and from the floating farms- has changed not only the use of bays by the fishing community (reflected in the reduced number of registered fishermen) but also the landscape of the beaches, which are now strewn with materials associated with salmon operations. The local people complain that the coast has become a dumping ground and that their algae harvesting activities now involve picking between the styrofoam floatation devices and plastic containers discarded by the nearby processing plants. According to BustosGallardo (2017), interaction between the salmon firms and local communities can be likened to a form of enclave, while Barton et al. (2013) focus on the effects of the processing plants on urban expansion, most notably in terms of the move from an urban configuration appropriate to the existing landscape (i.e., traditional Chilote architecture) to large-scale landscaping to create terraces on which to construct social housing near centres of production.

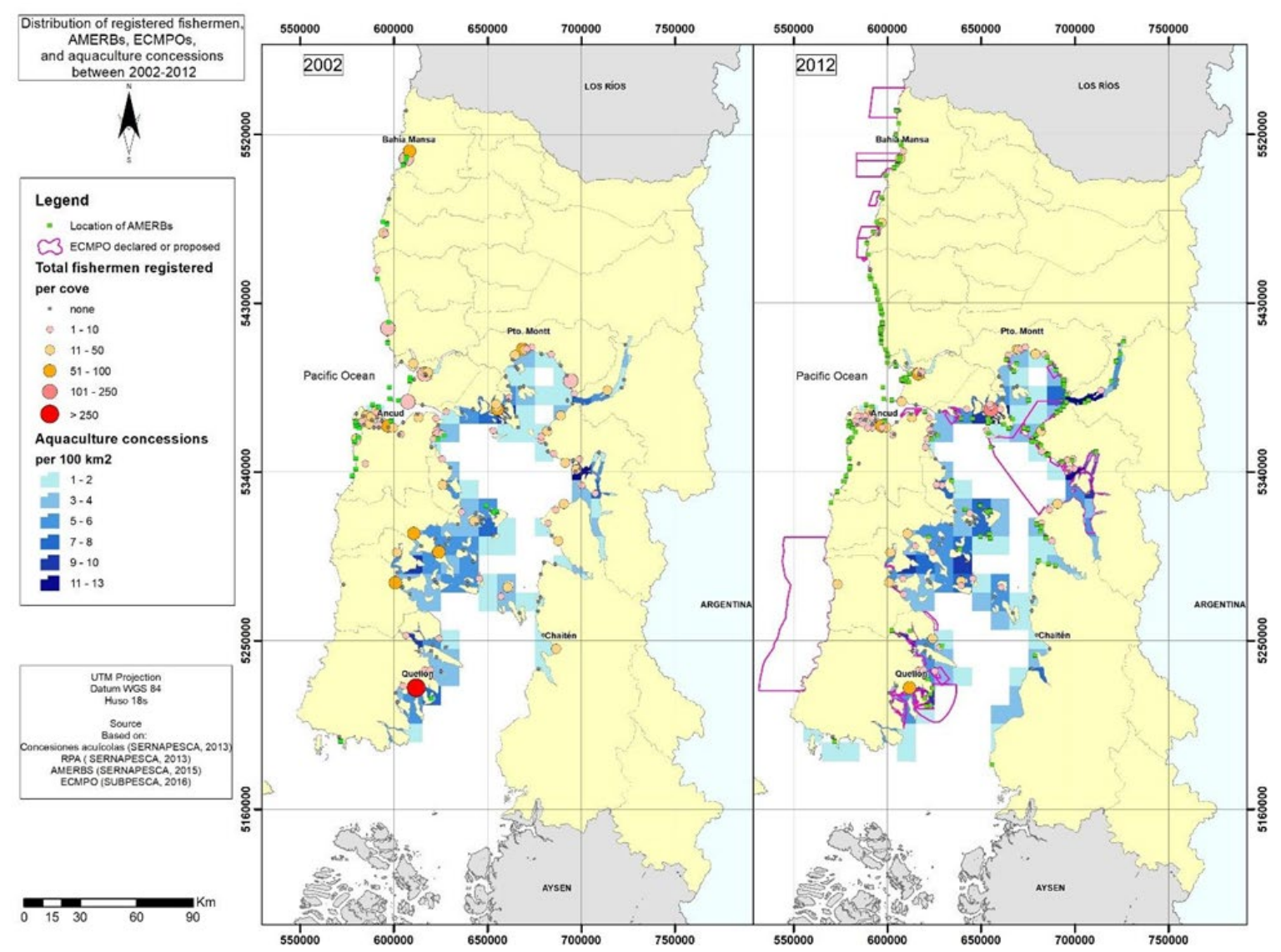

Figure 1: Historical evolution of artisanal fishing vs aquaculture concessions, 1992-2012. Source: cartographic team FR1160848.

Meanwhile, the emergence of salmon workers and unions as part of the social and political fabric of the island changed power dynamics, and eventually Indigenous communities were recognised by the Indigenous Law as legal entities with access to land and water property rights, a change which strengthened the 'Chilote/williche' identity as a political actor with legitimate claims against the state. A brief review of the history of social mobilisation on the island (Foullioux, 2018) reveals that previous events have been related to the understanding 
of effects and the distribution of benefits derived from the territorial transformations taking place on the island. However, none of these conflicts (over health provision, the construction of a bridge connecting the island to the mainland, and ecological degradation) targeted the salmon industry specifically, instead identifying the state as the primary opponent. In a way, the social and economic mobility of the Chilotes mitigated the impact of the socioecological transformations, and we argue that state subsidies and the creation of legal institutions that decide access to the sea caused fragmentation of the issue, while the salmon industry was perceived as a solution in terms of the jobs it created.

A paradox emerged: the more specialised the industry became, the weaker its connection with the locals, and the more dependent Chilotes became on state subsidies and benefits. The historical centralisation of the Chilean state also played a role in disconnecting the industry from the rural reality. While local authorities are democratically elected, they have no power to make decisions concerning local industries. In fact, over $90 \%$ of each of Chiloé's municipalities depend on central state redistribution policies, which come with a set of restrictions as to their use. It was only in 2014 (after the salmon industry had been affected by the ISA crisis) that a local salmon tax was implemented, but its effect on local finances and the development project is as yet unperceived by locals.

Chilotes have found themselves caught between a large-scale industrial complex accountable only to global shareholders, and a centralised state which offers no opportunities for participation in decision-making. Considering the 'fever-driven' component of the Chilote culture and political cycles, which included whale hunting in the 1940s, timber extraction in the 1980s, loco (Concholepas concholepas) extraction in the early 1990s, salmon production in the 1990s and 2000s, mussel cultivation in the 2000s, and peat extraction in the 2010s, the main message communicated by salmon production was that there was no need to move away, and that the length of each cycle could be controlled by people. Fever logic refers to the strategy pursued by Chilotes to rush into a new economic activity that represents an opportunity for better income, without much hesitation or consideration of its effects. Thus, while the social and economic stakes were much higher in the cases of the salmon and bloom crises, they did not represent a break from previous cycles of fever and crash. As such, the Chilote reaction to a crash had already been internalised: don't overthink; just move on to the next 'fever'. This strategy was applied during the 2008-2010 ISA crisis, when the industry's mode of production - viewed by the regional community as detrimental to their other modes of living - was not only reinstated by the state, but pushed forward with the help of new regulations. The lesson learned by the community was that the state would always side with industry, and that the potential of negotiation or altering the terms of production was minimal.

It is the neoliberal logic that helps explain the situation described above. Firstly, there was a profound distrust of political parties as legitimate agents to represent and resolve political disputes involved in conflicts: neoliberalism prioritises individuals and private actors over political groups, since collective wellbeing is best defined in terms of individuals. Secondly, individuals strive to solve their own problems, not those of society, meaning that the scope of themes discussed when addressing a conflict is restricted to those subjects of relevance to the individuals involved, and not necessarily the structural causes that lie behind the conflict.

We regard the relationship over the past 15 years between the Chilean state and Chiloé as configuring what Cramer (2016) refers to as 'politics of resentment'. Chilotes felt that the 
state was neglecting the island's trajectories and specificity, a feeling that went hand in hand with a growing sense of pride in their Indigenous, rural and islander identity values - founded on sense of community, tradition and place-and as such were opposed to the modern neoliberal ideas of individualism and globalisation. Finally, the accumulation of negative effects (environmental, social and economic) associated with the salmon industry lad to a feeling of unfairness in the distribution of benefits and burdens. As a result, when the 2016 algal bloom occurred, the state viewed it as a spontaneous phenomenon unrelated to the area's salmon production activities, while for locals, it was the last straw in the tense relationship between the island and the state.

\section{The mayo chilote}

Between January and April 2016, the sea around the Los Lagos region suffered two consecutive algal bloom events. The first involved the species Chattonella marina, and seriously affected salmon farms in the area. Some 40,000 tons of biomass had to be discarded, making it the country's second major salmon industry sanitary crisis to occur in less than a decade. The scale of the crisis forced the state to implement extraordinary measures for disposal of fish carcasses, mandating the dumping at sea of 4,600 tons at a distance of $70 \mathrm{~km}$ from the coast, near to the island's northernmost town, Ancud (Servicio Nacional de Pesca, 2016). However, the authorities' failure to properly monitor and enforce the policy left the community sceptical of the appropriateness of the measures.

One month later, on 7 April 2016, a second algal bloom (Alexander chattonella) spread rapidly across Chiloé's Inner Sea. Historically, the south of Chile has experienced frequent blooms of Alexander chattonella, but this particular event surpassed others in intensity and geographical spread, reaching farther north than usual. Alexander chattonnella is extremely dangerous to humans and may cause death if consumed. Chile's sanitary authority was therefore forced to implement a regional ban on harvesting shellfish, the island's second most important source of income. Table 1 describes how events unfolded, and the actions taken by the actors involved.

Table 1: Chronology of the mayo chilote, 2016. Source: compiled by the authors based on media coverage by national and regional press (www.aqua.cl, www.elmostrador.cl, www.emol.com, www.laestrelladechiloe.cl, www.latercera.com).

\begin{tabular}{|l|l|l|}
\hline Month & Main event (day) & Main actions (day and actors` involved) \\
\hline January & $\begin{array}{l}\text { (29) Chattonella sp. } \\
\text { bloom detected. }\end{array}$ & \\
\hline February & $\begin{array}{l}\text { (4) Red tide } \\
\text { detected in Aysén } \\
\text { Region and } \\
\text { Chiloé's Inner Sea. }\end{array}$ & $\begin{array}{l}\text { (2) (F) Salmon workers report mass layoffs in processing plants. } \\
\text { (18) } 1,500 \text { people participate in the 'Chiloé está privao' } \\
\text { demonstration in Castro. } \\
\text { farms due to Chattonella sp algal bloom. }\end{array}$ \\
\hline
\end{tabular}




\begin{tabular}{|c|c|c|}
\hline March & $\begin{array}{l}\text { (11-26) Salmon } \\
\text { mortalities } \\
\text { deposited in a } \\
\text { marine trench in } 11 \\
\text { stages (as reported } \\
10 \text { May). }\end{array}$ & $\begin{array}{l}\text { (3) (S) Health Ministry establishes partial closure of Chiloé's } \\
\text { fishing coves due to the red tide (Queilén south). } \\
\text { (4) (S) Marine Authority authorises dumping of } 9,000 \text { tons of } \\
\text { dead fish. } \\
\text { (14) (CS) Mapuche People Ancestral Authority Council } \\
\text { presents an appeal for protection to the Courts. }\end{array}$ \\
\hline April & $\begin{array}{l}\text { (7) Red tide } \\
\text { detected on the } \\
\text { west coast of } \\
\text { Chiloé island. } \\
\text { (24-26) National } \\
\text { press reports the } \\
\text { discovery of large } \\
\text { quantities of dead } \\
\text { razor clams in } \\
\text { Cucao (Chonchi). }\end{array}$ & $\begin{array}{l}\text { (20) (S) Health Ministry declares sanitary alert due to the red tide. } \\
\text { (25) (CS) } 1,000 \text { Artisanal fishermen march in Ancud. } \\
\text { (27) (CS) 1,500 artisanal fishermen submit their 4-point request: } \\
\text { 1. Declaration of state of catastrophe. } \\
\text { 2. Scientific sampling with greater geographical precision } \\
\text { to trace red tide bloom. } \\
\text { 3. Information campaigns about extraction and } \\
\text { consumption of marine products. } \\
\text { 4. Independent research to assess the role of salmon } \\
\text { disposal in triggering the red tide. } \\
\text { (29) (S) Los Lagos Region established as a Catastrophe Zone. } \\
\text { Government decrees financial compensation for } 500 \text { families. } \\
\text { (30) (S) Announcement that compensation will be worth } \\
\text { CLP100,000 (USD147 at the time). }\end{array}$ \\
\hline May & $\begin{array}{l}\text { (2) Mobilised } \\
\text { groups cut access to } \\
\text { the island at the } \\
\text { coastal cities of } \\
\text { Ancud and } \\
\text { Quellón. } \\
\text { (25) Government } \\
\text { lifts ban on } \\
\text { extraction and } \\
\text { consumption of } \\
\text { seafood from } \\
\text { Chiloé's Inner Sea. }\end{array}$ & $\begin{array}{l}\text { (5) (CS) 2,000 people march in Ancud. } \\
\text { (7) (CS) 7,000 people march in Ancud. } \\
\text { (15) (CS) Organisations from } 6 \text { municipalities accept } \\
\text { government offer to end mobilisations. } \\
\text { (19) (CS) Fishermen from Ancud agree to end mobilisations, } \\
\text { accepting: } \\
\text { - financial compensation of CLP750,000 (US } \$ 1,113 \text { at } \\
\text { the time) for nearly } 6,000 \text { families; } \\
\text { - participation of representatives from the artisanal fishing } \\
\text { community as observers in the scientific task force } \\
\text { created to investigate the connection between salmon } \\
\text { disposal and the red tide; } \\
\text { - implementation of a taskforce to promote job creation } \\
\text { on the island. } \\
\text { (25-31) (S) Scientific task force (including } 2 \text { fishermen) } \\
\text { participate in fieldwork in Chiloé to measure and assess the red } \\
\text { tide. }\end{array}$ \\
\hline
\end{tabular}

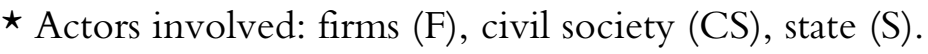

The community reacted with anger to the ban. The Chilotes' traditional flexible economic strategy of movement from one activity to another according to present conditions had been made impossible over time, as expansion of the salmon industry constrained their traditional economic activities (Fløysand \& Román, 2008; McPhee, 2015). The tradition of going fishing when times were hard was made impossible by regulatory arrangements such as quotas and permits (Pavez, 2015), and the coastal economy of seaweed and shellfish harvesting fell prey 
to the same industrialisation as salmon production. These activities were directly affected by the ban, leaving Chilotes with no means of weathering the storm.

The government's response to community anger was slow. There was a lack of understanding of the social problems triggered by the ban, and the meagre financial assistance offered was viewed as an insult by locals. The initial one-off figure of approximately US $\$ 150$ per family was later increased to three payments totalling US $\$ 1,000$, and the dialogue that eventually yielded this final figure represented the biggest social conflict in regional history. The Interior Ministry defended its decision, stating that "this is not a government with an open purse policy" (Vargas, 2016, 4 May), and backlash among islanders was immediate; nevertheless, they were left waiting for a week for any response or apology from the government. By 12 May, the government had acknowledged its delay in "understanding the true scale of the problem" (Jiménez, 2016, 12 May), but during the ensuing negotiations refused to consider other issues on the table. The Minister for the Economy-appointed as special deputy by President Bachelet and tasked with negotiating a solution to the conflictstated that "our proposal addresses the majority of the demands, including an initial payment of CLP300,000; however, we refuse to discuss issues that are not related to the red tide" (Emol, 2016, 6 May).

Protesters blocked the island's access points, preventing the arrival and departure of ferries, and barricades were installed on the island's main roads. Over a period of three weeks, at least two marches took place each day in the towns of Castro and Ancud, and social media played an important role in communicating the feelings and reactions of the Chilotes. National media outlets were quick to cover the conflict, increasing concern around the country.

The government restricted eligibility for financial compensation to those artisanal fishermen who appeared on the official register, a move which illustrated the government's inability to grasp the complex web of interactions between the different livelihoods that exist on the island. A given person may be not only a farmer, but also a fisherman, a tour guide, and a labourer; as a result, possession (or not) of a permit is not traditionally relevant for use of natural resources. The mobilisations came to an end on 19 May, when communities from Ancud reached an agreement with the government to secure instalments of US $\$ 450$ per month for three months awarded to a total of around 5,500 people.

A year on, social organisations called for commemorative events to be held to reflect upon the experiences and learning outcomes of the mayo chilote; however, the few events organised suffered poor attendance. Moreover, a survey conducted in 2017 revealed that Chilotes are, despite widespread criticism, generally in favour of industrial salmon farming (Universidad de Los Lagos, 2018). It became apparent that people who had been so actively engaged in the mobilisation only 12 months previously had already moved on. We believe that the explanation lies not in the state's solution of compensation, but in deeper perceptions of development and the relationship between island and nation.

\section{Expressions of islandness during May 2016}

Throughout the course of the mobilisations, a core element that guided the action of participants was a feeling of connection to the sea and the desire to protect it. It was the sea to which fishermen, salmon workers, and even farmers would turn in times of need, either for subsistence or economic gain, and this sea—so central to the Chilote identity—was being 
abused and neglected by the salmon industry and the state. It is symbolic that the motto of the mobilisations was "Chiloé está privao" (Chiloé is angry), and many of the banners and signs connected that anger to the state of the sea. While the industry and the state are in different ways responsible for the algae bloom crises, resentment toward the state was central to the action of the Chilotes.

We argue that the events of May 2016 exposed the emergence of islandness as a political position, but one that is divided into two distinctive narratives. One was concerned with the distribution of benefits and burdens (represented primarily by the fishermen), and the other focused on autonomy as a core concept of development (represented by radical groups). In what follows, we focus on two particular issues of contention in order to offer a description of each narrative as expressed during the mobilisations.

The redistributive narrative derives from years of abandonment of local communities by the state, during which time the industry expanded and profited from the archipelago's resources. While it is implicitly disconnected from any particular actor, the narrative draws on unionism and labour opportunities for inhabitants in salmon farming, and thus is more explicit in its pursuit of monetary compensation. The autonomy as development narrative calls for an alternative and autonomous path forward. More explicitly based on identity positions, the main premise of this critique is the unwanted deterioration of the social fabric that threatens the cultural particularity of the archipelago, and it draws on the communitarian practices that lie at the core of Chilote cultural traditions. As such, this critique covers a longer time-frame, encompassing the last three decades of economic growth during which the adoption of a monetary approach to social relations and dependence on wage labour instead of self-sufficiency has driven the loss of traditional practices.

The first distinction addresses the causal effects and reparation measures involved in the crisis. The fishermen were quick to assign culpability to the government - firstly for allowing the salmon farms to dispose of fish carcasses near the Chiloé coast, and secondly for imposing sanctions on artisanal fishing activities - and consequently to demand proper compensation for their economic losses. In conflicts relating to use of coastal areas, fishing quota distributions and pollution by chemical substances used in salmon cultivation, the state was identified as the responsible party:

In the eyes of the Chilean state, we artisanal fishermen are a nuisance. They want to do away with us through restrictions and impoverishment, and put an end to one of humanity's oldest professions. Through the Fisheries Law and the salmon industry, they want to eradicate us and leave the sea around Chiloé open to exploitation (leader of artisanal fisher union).

The distributive message of this narrative is evidenced by its criticism of the state. Although anger is expressed against the salmon industry, the original cause of the problem was identified as the authorisation by the Fisheries Undersecretariat to use the sea around Chiloé as a dumping ground. A further discussion surrounded the actual definition of artisanal fishermen, taking account of the diverse roles and practices involved along the production chain. The debate was presented in monetary terms, with the goal being to include as many people as possible in order to truly represent all of those directly affected by the algal bloom. By contrast, while also blaming the government to an extent, radical groups framed the 
problem as historical abandonment and the creation by the industry of a sacrifice zone around Chiloé. As such, responsibility lay with the industry for dispossessing Chiloé of its natural endowments, upon which autonomous development would have naturally taken place.

The mobilisation united a number of stakeholders in criticism of salmon industry behaviour in the region, but also in opposition to the state's promotion of a one-sided approach to development. Despite general consensus, opposition was fraught with divisions, with the two main actors pursuing incompatible objectives. The fishermen demanded compensation from the public sector on the basis of state responsibility for uncontrolled salmon production, while the radical groups sought to secure structural changes to the local economy:

We don't want to wake up tomorrow and find the whole island like the north: devastated, a rubbish heap. We are the backyard of Chile. [...] These days the aim is profit, profit, profit. They want to just come in and do as they please without any consideration for us. Human beings live here: the Chilotes (seaweed harvester and social leader).

In the absence of the state, the mingas are good, the medanes are good. Faced with so much apathy from central power, so much contempt for our territory, autonomous cultural practices are being refined over time (Chilote).

The second distinction refers to questions concerning the purpose of Chiloé. In light of the 2008 sanitary crisis, redistributive discourses on salmon farming prior to May 2016 expressed little confidence in the industry's future. It was generally agreed that the crisis was generated by unsustainable practices, such as overcrowding of salmon cages, over-medication of fish, and accumulation of waste on the sea-bottom as a result of overfeeding. Despite the intense campaign led by SalmonChile (main industry lobby agency) and the salmon farming companies to change these practices-mostly with a view to improving producer competitiveness-local stakeholders perceived efforts as superficial given the lack of environmental regulation, the focus on short-term revenues, and the almost complete absence of state intervention:

I am worried that there will be another sanitary crisis and that the industry... well... everything revolves around the industry, and we don't have anything else to fall back on (union leader).

This quote expresses the fear of fresh disasters, and was central to calls for compensation as a tool to resolve Chiloé's latest conflict. It relates to the economic view of development which proposes that assets can be traded for money. In this case, given the way in which the conflict was resolved, the ban on shellfish extraction was seen as a monetary problem rather than an environmental one. It was a distributive discussion that juxtaposed responsibility for production practices on the part of salmon companies with regulatory action on the part of public agencies. The industry benefited from being allowed to dispose of fish waste in the sea, but the costs were endured by the artisanal fishermen, as according to them, the red tide had directly followed the disposal of fish waste. 
Narratives of autonomy as development stressed that the salmon industry became a device for assimilation of the region into the national project. In contrast to the usual characterisation of such tools as yet another miracle of the Chilean economy, the mayo chilote represented an opportunity to report and critique the ongoing pattern of fever exploitation. Even if local inhabitants are able to take part and benefit from them, the general consensus of the island's population is that this state-promoted approach has done nothing more than pollute:

Throughout its history, the province of Chiloé has been plundered. It has constantly been exploited; ransacked for its natural resources. It's undeniable. For forestry, for locos, for shellfish, etc. (local historian).

The sea is the source of life and subsistence for Chilotes, and now they are treating it as an object, abusing it economically. Often, the salmon companies do not even make use of their concessions: the idea is to hoard cheap land and sell it on later at a higher price. That's how they work (seaweed harvester).

The autonomy as development narrative argues that this failure of the industry should be seen as a point at which to return to the roots of Chilote identity and autonomy: the land and the multifunctional strategies that allowed the island to sustain its inhabitants. Words like 'ethnotourism' and 'self-sufficiency' were used to portray an alternative to the modern path to wellbeing, whereby historical traditions may be rediscovered as core building blocks for the future:

No one tells us about the Chilotes that boarded the schooner Ancud to go and conquer Magallanes. We are educated not even to recognise ourselves. We are taught that we are underdeveloped and that someone from outside must come to save us (Chilote).

\section{The resulting islandness}

Although the social mobilisation of 2016 was not uniform, the state was at the centre of the dispute. Discourses ranged from those that demanded greater flexibility on the part of salmon companies to allow social reproduction of traditional practices (thus ensuring economic diversification on a local basis), to those that reflected critically on how to create the conditions in Chiloé in which different development paths could be deployed:

Here in Chiloé we have a bit of everything. Everything. The territorial opportunities are immense. We don't have just one option. Besides, we have both sea and land. So you can have snails, seaweed, smoked fish, with added value, or bring along a transformative industry - a technological industry- to promote small-scale agriculture, opt for agroecology, and bring added value to family farming. Smallscale, artisanal industries. Vocational and arts schools, technical courses in marine sciences and tourism. Vocational and arts schools to recover traditional knowledge, a small-scale creative industry. It doesn't all have to be on a huge scale (environmental NGO representative). 
We need to move toward a more advanced state of awareness regarding the effects of the extractivist model that the salmon industry represents (Chilote scholar).

Such narratives are directed toward the definition of priorities and local decisionmaking, and toward avoiding a situation in which the state controls the various productive activities within a given territory. It is in this context that we are able to identify a sense of community in the face of continental powers (Conkling, 2007), whereby demands rather than requests are made. The narrative also defies the normative definitions of productive activities in the archipelago (Lois, 2013) by criticising export- and industry-based models of economic growth, and opposing notions of development based on incorporation into global value chains. The fact that the mobilisations lasted for almost three weeks and united social groups and other stakeholders that were traditionally opposed to one another is an indication of the sense of community that ultimately gave the mobilisation its insular character:

What was the big victory of the mobilisation in Chiloé last year? In terms of tangible achievements: nothing. In terms of political and social achievements: it was tremendous. It broke the taboo and let people know that yes, I can question the existence of the salmon industry without being frowned upon by my neighbours and family who work on the fish farms (radical group member).

Thus, while the ultimate impact of the mayo chilote may be rather modest, it helped to set expectations that had been absent for more than three decades of salmon farming and monoculture-based development. Earlier attempts to conduct environmental assessments of salmon aquaculture were contested by the unions, which feared a loss of investment as a result of the introduction of more stringent regulations. This time around, a sense of tragedy led to the expression of new discourses, but these were ultimately silenced by what Barton and Fløysand (2010, p.743) call the "economic imperative," whereby evidence of social and environmental damage was ignored in favour of Chiloé's extraordinary economic dynamism during the 1990s.

\section{Understanding May 2016}

For those who participated, the social feeling three years after the mobilisations is of reluctance to accept that things remain more or less the same as before, despite the intensity of events at the time. For the most part, participants remember the events as a lost opportunity; it was less a process and more a moment of anger release; of facing up to the authorities and voicing a demand rather than the beginning of a long-term process of building a new era for Chiloé.

The fact that the 2016 mobilisations were more a clash of development narratives about the future of Chiloé as an island, shows how islandness has become a political position in opposition to the state. However, while a clear narrative was promoted by certain Chilote actors regarding the needs and potential of the island, the modernisation ideal still prevails among its inhabitants. Although the salmon industry has failed over the past decade to deliver the modern promise, it has succeeded in constructing a commodity region that is both perfect for and dependent upon salmon production. That islandness has become a political position does not mean that it is a unitary position. No matter how effective islandness is at uniting a 
diversity of social demands, fragmentation is always a certainty, and even active participation with the state to address them can be used as a mechanism to dilute and contain discontent.

Today, Chilotes blame the state not only for its commitment to guaranteeing the continuity of the industry, regardless of the latter's effect on the island, but also for the exclusion of locals from the political and administrative structures within which decisions about the environment and economic practices are taken. The concept of islandness thus needs to be understood as a political position that exposes the range of assessments of the power asymmetries between islanders and the state, and which is also grounded in the politics of resentment. It is a view that romanticises the past and rejects current economic reading of the landscape as one of resources, and communicates despair at the indifference of the state to the material conditions of living on the island. In that sense, islandness comprises a powerful mix of disappointments, frustrations and truthfulness. Despite its weak structural effects, it was the notion of islandness that made possible an open political debate concerning opportunities and alternatives for Chiloé's development, taking into consideration the island's past and present in a context of tradition, modernity and industrialisation.

Finally, therefore, we invite island studies scholars to explore how islandness as a political position allows us to understand islanders' reactions to rapid changes, centralism and integration into global commodity chains, and its manifestation in radical political positions.

\section{Acknowledgements}

The authors acknowledge the support provided by the following research funding sources: CONICYT/FONDECYT/1160848, CONICYT/FONDECYT/3170740 and CONICYT/FONDECYT/1161417.

\section{References}

Baldacchino, G. (2005). The contribution of 'social capital' to economic growth: lessons from island jurisdictions. The Round Table, 94(1), 31-46. https://doi.org/10.1080/00358530500033075

Barrett, G., Caniggia, M.cI., \& Read, L. (2002). 'There are more vets than doctors in Chiloé': social and community impact of the globalization of aquaculture in Chile. World Development, 30(11), 1951-1965. https://doi.org/10.1016/S0305-750X(02)00112-2

Barton, J. R., \& Fløysand, A. (2010). The political ecology of Chilean salmon aquaculture, 1982-2010: a trajectory from economic development to global sustainability. Global $\begin{array}{lll}\text { Environmental } & \text { Change, } & \text { 739-752. }\end{array}$ https://doi.org/10.1016/j.gloenvcha.2010.04.001

Barton, J. R., Pozo, R., Román, Á. \& Salazar, A. (2013). Reestructuración urbana de un territorio glocalizado: una caracterización del crecimiento orgánico en las ciudades de Chiloé, 1979-2008. Revista de Geografía Norte Grande, 56, 121-142. https://doi.org/10.4067/S0718-34022013000300007

Barton, J. R., \& Román, Á. (2016). Sustainable development? Salmon aquaculture and late modernity in the archipelago of Chiloé, Chile. Island Studies Journal, 11(2), 651-672. 
Bustos-Gallardo, B. (2017). The post 2008 Chilean salmon industry: an example of an enclave economy. The Geographical Journal, 183(2), 152-163. https://doi.org/10.1111/geoj.12204

Bustos, B., \& Prieto, M. (2019). Nuevas aproximaciones teóricas a las regiones-commodity desde la ecología política. EURE, 45(135), 5-29. https://doi.org/10.4067/S0250$\underline{71612019000200153}$

Conkling, P. (2007). On islanders and islandness. The Geographical Review, 97(2), 191-201. https://doi.org/10.1111/j.1931-0846.2007.tb00398.x

Cramer, K. (2016). The politics of resentment: rural consciousness in Wisconsin and the rise of Scott Walker. Chicago: University of Chicago Press. https://doi.org/10.1111/ruso.12174

Daher, A. (2003). Regiones-commodities: crisis y contagio en Chile. EURE, 29(86), 89-108. https://doi.org/10.4067/S0250-71612003008600005

Ducros, H. B. (2018). Reclaiming islandness through cloth circulation in Madagascar. Island Studies Journal, 13(2), 25-38. https://doi.org/10.24043/isj.69

Emol (2016, May 6). Gobierno "lamenta" no haber podido llegar a un acuerdo con pescadores artesanales.

https://www.emol.com/noticias/Nacional/2016/05/06/801423/Gobiernolamenta-no-haber-podido-llegar-a-un-acuerdo-con-pescadores.html

Fløysand, A., Barton, J. R., \& Román, Á. (2010). La doble jerarquía del desarrollo económico y gobierno local en Chile: el caso de la salmonicultura y los municipios chilotes. EURE, 36(108), 123-148. https://doi.org/10.4067/S0250-71612010000200006

Fløysand, A., \& Román, Á. (2008). Industria salmonera, sistemas de innovación y desarrollo local: el punto de vista de las municipalidades de Chiloé. Bergen: Department of Geography, University of Bergen.

Fouilloux, I. (2018). Movimientos sociales y "commoditización" del territorio: el caso de los movimientos sociales ante el desarrollo de la industria salmonera en el archipiélago de Chiloé (1980-2016). Thesis to obtain the degree of Sociologist. Santiago, Chile: University of Chile. https://doi.org/10.4206/rev.austral.cienc.soc.2014.n26-10

Hay, P. (2013). What the sea portends: a reconsideration of contested island tropes. Island Studies Journal, 8(2), 209-232.

Hayward, P. (2012) Aquapelagos and aquapelagic assemblages. Shima, 6(1), 1-11.

Heidegger, M. (2009). El arte y el espacio. Barcelona: Herder.

Hidalgo, C., Ther, F., Saavedra, G., \& Díaz, A. (2015). Affordance of landscapes and economic socio-spatial networks in the Quinchao archipelago, Chile: a contribution to landscape research and island studies. Island Studies Journal, 10(1), 49-70.

Jiménez, M. (2016, May 12). Crisis en Chiloé: La Moneda admite tardía reacción y califica negativamente frase de Burgos sobre "billetera fácil". https://doi.org/10.24275/uami.ft848q60n

Lois, C. (2013). Isla vs. continente: un ensayo de historia conceptual. Revista de Geografía Norte Grande, 54, 85-107. https://doi.org/10.4067/S0718-34022013000100006

Mascareño, A., Cordero, R., Azócar, G., Billi, M., Henríquez, P. A., \& Ruz, G. A. (2018). Controversies in social-ecological systems: lessons from a major red tide crisis on Chiloe Island, Chile. Ecology and Society, 23(4), 15. https://doi.org/10.5751/ES$\underline{10300-230415}$ 
McPhee, B. (2015). Irrupción de nuevas ruralidades en Chiloé Central. In Á. Román, J. R. Barton, B. Bustos, \& A. Salazar (eds.). Revolución salmonera: paradojas y transformaciones territoriales en Chiloé (pp.125-149). Santiago: RIL Editores; Instituto de Estudios Urbanos y Territoriales UC.

Mountz, A. (2015). Political geography II: islands and archipelagos. Progress in Human Geography, 39(5), 636-646. https://doi.org/10.1177\%2F0309132514560958

Melucci, A. (1995). The process of collective identity. In H. Johnston \& B. Klandermans (eds.). Social movements and culture (pp.41-63). Minneapolis: University of Minnesota Press.

Ong, A. (2006). Neoliberalism as exception: mutations in citizenship and sovereignty. Durham, NC: Duke University Press. https://doi.org/10.1017/s030574100600097x

Pavez, C. (2015). Salmonicultura y nuevos pescadores: relaciones de cooperación y conflicto. In Á. Román, J. R. Barton, B. Bustos, \& A. Salazar (eds.). Revolución salmonera: paradojas y transformaciones territoriales en Chiloé (pp.181-206). Santiago: RIL Editores; Instituto de Estudios Urbanos y Territoriales UC.

Pugh, J. (2018). Relationality and island studies in the Anthropocene. Island Studies Journal, 13(2), 93-110. https://doi.org/10.24043/isj.48

Pugh, J. (2016). The relational turn in island geographies: bringing together island, sea and ship relations and the case of the Landship. Social \& Cultural Geography, 17(8), 10401059. https://doi.org/10.1080/14649365.2016.1147064

Pugh, J. (2013). Island movements: thinking with the archipelago. Island Studies Journal, 8(1), 9-24.

Randall, J. E., Kitchen, P., Muhajarine, N., Newbold, B., Williams, A., \& Wilson, K. (2014). Immigrants, islandness and perceptions of quality-of-life on Prince Edward Island, Canada. Island Studies Journal, 9(2), 343-362.

Rankin, J. R. (2016). Tracing archipelagic connections through mainland islands. New Zealand Geographer, 72(3), 205-215. https://doi.org/10.1111/nzg.12138

Servicio Nacional de Pesca (2016). Informe fiscalización de la resolución D.G.T.M y M.M. Ord. n¹2.600/05/114/vrs, de la Autoridad Marítima relativa al vertimiento de desechos de salmones. (n. p.): Servicio Nacional de Pesca. https://doi.org/10.2307/j.ctvdmx0vf.6

Universidad de Los Lagos (2018). Resultados Encuesta de Conflictos Socio-Territoriales 2017. https://doi.org/10.18411/a-2017-023

Vannini, P. (2011). Constellations of ferry (im)mobility: islandness as the performance and politics of insulation and isolation. Cultural Geographies, 18(2), 249-271. https://doi.org/10.1177\%2F1474474010397597

Vargas, F. (2016, 4 May). Jorge Burgos y crisis en Chiloé: "Este es un gobierno que va en ayuda de la gente, pero no es un gobierno de billetera fácil". https://doi.org/10.5209/rev cgap.2015.v2.n2.51572 
Beatriz Bustos E Álvaro Román 